\title{
PALESTINIAN REFUGEES IN SYRIA DURING THE SYRIAN CIVIL WAR
}

\author{
Marcin Szydzisz \\ Institute of International Studies \\ Faculty of Social Sciences \\ University of Wroclaw
}

\begin{abstract}
The article is an attempt to describe situation of Palestinian refugees during the Syrian Civil War. The author explains the attitude of the conflict's main parties towards Palestinians. The paper also presents the stance of Palestinian parties (Hamas and PLO) and Palestinian refugees towards the Assad regime and rebels. Unfortunately, fights have been occurring in Palestinian camps, too (especially in the Yarmouk camp), so Palestinians are also victims of the conflict.
\end{abstract}

Key words: Palestine, Palestinian refugees, Syria, Yarmouk camp

During the 1948 war that established Israel's existence, about 750,000 Arabs who had lived in Mandatory Palestine fled or were expelled from their homes. Almost 70,000 of them fled to Syria. They came mainly from the northern part of Palestine - Safad, Haifa, Acre, Tiberias, Nazareth and Jaffa. The majority of Palestinian refugees were settled along the border area with Israel. After the 1967 war, another 100,000 people, some of whom were Palestinian refugees, fled from the Golan Heights to other parts of Syria. According to UNRWA (the United Nation Relief and Works Agency for Palestinian Refugees) there are 560,000 registered Palestinian refugees ${ }^{1}$, almost three percent of the total Syrian population $^{2}$. Some of these refugees lived in thirteen camps, nine of which are acknowledged by UNWRA (constituting about $30 \%$ of the Palestinian refugee population), while the other four camps are recognized only by Syrian govern-

1 http://www.unrwa.org/syria-crisis April 16, 2015.

2 Palestinian Refugees from Syria: Ongoing Nakba, Ongoing Discrimination "Al Majdal”, BADIL Resource Center for Palestinian Residency and Refugee Rights, Issue No.56 (Autumn 2014) p. 2, http://badil.org/phocadownload/Badil_docs/publications/al-majdal-56.pdf, access: April 16, 2015. 
ment (they were created after the establishment of UNWRA). The biggest of "unofficial" camp - Yarmouk is located--near the centre of Damascus. It hosts more than 25\% of all Palestinians in Syria, and is considered the Palestinian cultural and economic heart in Syria ${ }^{3}$.

The legal status of Palestinian refugees was established in 1957. They have the same duties and responsibilities as Syrian citizens, but they do not have citizenship and political rights. Palestinian men had to undertake military service but they served in separate formations--in the Palestine Liberation Army under the Syrian Command. There are no restrictions regarding right to employment ${ }^{4}$. In 1996 around 41\% of Palestinians in Syria worked in the service sector, 27\% in construction branch, and $15 \%$ in the industry sector ${ }^{5}$. The economic condition of Palestinian refugees was similar to that of Syrian citizens. According to a 2003 FAFO study, Palestinians were better integrated into Syrian society than were their counterparts in Jordan and Lebanon ${ }^{6}$.

In 2006 nearly all Palestinian households reported that they owned their dwelling ${ }^{7}$, even though they were only allowed to own houses in $1968^{8}$. Palestinian refugees in Syria can usually write and read; in 2001, only $9 \%$ were totally illiterate. The Ministry of Education reported that $80 \%$ of Palestinian children attended UNRWA schools and $17 \%$ are enrolled in government schools 9

There are two different organisations that tried to help Palestinian refugees. In addition to UNRWA, there is the General Administration for Palestine Arab Refugees (GAPAR), a government structure. This body was established in 1950 as part of the Ministry of Labour and Social Affairs ${ }^{10}$. The GAPAR is responsible for "organizing, relieving and securing different needs for refugees, in addition to allocating suitable jobs for them"11.

3 Palestinians from Syria. Syria Needs Analysis Project - March 2014, http://reliefweb.int/ sites/reliefweb.int/files/resources/palestinians_from_syria_march_2014.pdf, access: April 16, 2015.

4 In Syria there are four diffrent categories of Palestinian refugees (the 1956 category, the 1967 category, the 1970-1971 category and 2006 category). They have separated status (differences are in the lack of right to travel documents and impossibility to participate in military service). T. Hammound, Palestinian Refugees and the Syrian Revolution, Arab Center for Reaserch Policy Studies, Doha (February 2013), p. 3.

5 S. Shafie, Palestinian refugees in Syria, http://www.forcedmigration.org/research-resources/expert-guides/palestinian-refugees-in-syria/fmo017.pdf, access: April 16, 2015.

6 Palestinians from Syria...

7 L. Jacobsen, Housing and infrastructures, Palestinian refugees in Syria ..., p. 33.

8 They are still not allowed to own farm land. S. Shafie, op. cit.

9 Palestinians from Syria. Syria Needs Analysis Project-March 2014...

10 Ibidem.

11 Palestinian Refugees from Syria: Ongoing Nakba, Ongoing Discrimination, op. cit. 


\section{ATTITUDES OF THE PARTIES OF THE SYRIAN CIVIL WAR ABOUT PALESTINIANS AND PALESTINIAN ISSUES}

After the outbreak of the Syrian revolution in 2011, the Syrian regime tried to win over all Palestinian refugees. During the $63^{\text {rd }}$ anniversary of the Nakba in May 2011, thousands of refugees gathered near the borders of Israel. They sought to emphasize that they had not given up their right of return ${ }^{12}$. Certainly, protesters would not have been able to the reach the border without the approval of the Syrian government ${ }^{13}$. The regime attempted to unify society and to show that there is a common external enemy, and Israel is always a perfect candidate for this role. A similar situation took place in June 2011. During these protest, a few residents of Yarmouk Camp were killed at the Israeli border. In this case, Palestinian refugees in Yarmouk accused the authorities of being responsible for the deaths of the protesters. Fights between demonstrators and the Popular Front of the Liberation of Palestine-General Command (PFLP-GC) that supported the Assad regime (Party leaders encouraged camp residents to participate in Nakba Day events) started in the camp ${ }^{14}$. While on one hand the Syrian government tried to win over Palestinians, on the other hand it blamed them for the riots. The first protest started in Deraa in March 2011. The local authorities and pro-regime newspaper al-Watan accused Palestinians of inciting "acts of sabotage". Similar accusations occurred after demonstrations in other cities. During a press conference on March 26, 2011 Buthaina Shaaban (political and media advisor to President Assad) said that Palestinian groups from the Raml Camp had "sabotaged commercial stores and begun the project of sedition"15. This was the first official statement directly blaming Palestinians. Later, some Syrian politicians tried to discipline Palestinians. Jihad Makdissi, the Syrian foreign ministry spokesman, wrote on Facebook that "guests in Syria have to respect the rules of hospitality" or "depart to the oases of democracy in Arab countries"16. Allegations concerning Palestinians were primarily an attempt to manipulate society. The idea was to indicate the "external" (non-Syrian) source of the protests. This was particularly noticeable at the beginning of the conflict; it ended when the demonstrations spread to other parts of the country where Palestinians did not live.

${ }^{12}$ Unfortunately about 20 people were killed by Israeli soldiers. Four of them on the Golan Heights border. Palestinians killed in 'Nakba' clashes, http://www.aljazeera.com/news/middleeast/2011/05/2011515649440342.html, access: April 21, 2015.

${ }^{13}$ Z. Ali, A. Zayed, The Arab Spring and Reviving the Hope of Return, No 52, Spring 2013, http://www.badil.org/en/publication/periodicals/al-majdal/item/1928-art6.html April 21, 2015.

${ }^{14}$ The PRFL-GC militants opened fire to the crowd. They killed 14 persons. Report: 14 Palestinians killed in Syria camp, http://www.maannews.com/Content.aspx?id=394412, access: April 21, 2015.

${ }^{15}$ T. Hammoud, op. cit., p. 9.

${ }^{16}$ After the outcry, he removed his comments. S. Nashashibi, The Palestinian dilemma over Syria "The Guardian", http://www.theguardian.com/commentisfree/2012/jul/27/palestinian-dilemma-syria, access: April 28, 2015. 
Afterwards, the Syrian government did not take "organized pro-Palestinian" actions any longer. Moreover, the government military service sometimes attacked Palestinian camps. In August 2011, they invaded a camp in Latakia. On 3 August 2012, there was an attack on the camp in Yarmouk that resulted in 21 civilians being killed $)^{17}$. On 16 December 2012, Yarmouk Camp was bombed from the air and press reports indicated that at least 25 civilians were killed ${ }^{18}$. In April 2013, 6 000 residents of Ein el-Tal refugee camp were forcibly displaced in a single day "following months of sporadic armed engagements" 19

Parties connected with the rebels did not emphasize Palestinian issues. Insurgents were sometimes oppressive toward the Palestinians. In April 2013, 6000 Palestinians were forced out of the Ein El Tal camp in Aleppo by opposition forc$\mathrm{es}^{20}$. ISIS was also an oppressive force, especially during the attack on Yarmouk (April 2015). After that event the Assad regime drew attention to the Palestinians. During a meeting with PLO envoys Syrian authorities promised "to support the Palestinian fighters in a number of ways, including militarily, to push IS out of the camp". The Deputy Foreign Minister of Syria Faisal Meqdad added "Syria and the PLO are determined to fight terrorism, which has reached Palestinian camps in, notably Yarmouk," according to PLO official Anwar Abdul Hadi, who was at this meeting ${ }^{21}$.

Palestinians definitely were not at the centre of attention of the parties fighting in the Syrian conflict. Again, unfortunately, they were treated objectively.

\section{PALESTINIAN REFUGEE ATTITUDES TOWARDS SYRIAN CIVIL WAR}

The situation of the Palestinian refugees in Syria during the revolutions was very complicated. At the beginning of the civil war, most Palestinian leaders, organisations and officials were generally silent and tried to be neutral. After the accusations of supporting anti-regime demonstrations in March 2011, a number of Palestinian leaders stressed the neutrality of the camp and condemned its opinions $^{22}$. Neutrality was a Palestinian strategy. Support for one of side of conflict was very dangerous. Most Palestinian refugees remembered the situation in Lebanon

${ }^{17}$ At least 21 killed in shelling on Yarmouk Palestinian refugee camp in Syria: NGO, http:// english.alarabiya.net/articles/2012/08/03/230127.html, access: April 28, 2015

${ }_{18}$ Syrian planes hit Yarmouk mosque killing dozens, http://www.euronews.com/2012/12/16/ syrian-planes-hit-yarmouk-mosque-killing-dozens/, access: April 28, 2015.

19 Palestinian Refugees from Syria: Ongoing Nakba, Ongoing Discrimination, op. cit., p. 3.

${ }^{20}$ Palestinians from Syria. Syria Needs Analysis Project - March 2014 ...

${ }^{21}$ Syrian Deputy Foreign Minister Faisal Meqdad added "Syrian government had used all its efforts to present humanitarian and medical aid to Palestinian refugees and that it had helped them exit Yarmouk safely". Syria Offers Palestinians Military Aid against ISIS in Yarmouk, http:// www.israelnationalnews.com/News/News.aspx/193793\#.VUOVu_1_v5M, access: April 29, 2015.

${ }^{22}$ T. Hammoud, op. cit., p. 9. 
(Sabra and Shatilla massacres), the expulsion Palestinians from Kuwait during the first Gulf War in 1990, and the traumatic experience in Iraq after the U.S. invasion in $2003^{23}$. However, in some situations neutrality could not be maintained. According to the opinion of Eline Gords "Palestinians were divided on the anti-government protests: Some identified with the rebels, while others supported the Assad government" ${ }^{24}$. Similarly, Pinhas Inbari ${ }^{25}$ wrote, "Toward the end of July 2012, when the rebels had penetrated Damascus, the Palestinians were put in a difficult position. On the one hand, the insurgents attacked them at Yarmouk and they were forced to defend themselves, while, on the other, some Palestinians switched to the rebels' side and acted against the regime"26.

I will try to present two different attitudes about this conflict.

\section{PRO-REGIME ATTITUDE}

Syria tried to be a regional power. Syrian governments have always attempted to present themselves as an ally of the Palestinians and their cause, but the Palestinian issues was treated like an object. Magda Qandil wrote "The relatively fair treatment of Palestinian refugees inside Syria did not hinder the country's previous long-term president Hafez al-Assad from systematically using the Palestinian resistance as a political tool and ensuring that no independent Palestinian power centre emerged in the region, as it could have challenged his hegemonic position. The Syrian leader, in his attempts to control the Palestinian political leadership, instigated divisions and created its own Palestinian proxies, as well as backed assaults on Palestinian refugee camps in Lebanon during the country's civil war" ${ }^{\prime 27}$. The same policy was pursued by Hafez al-Assad son, the current president, Bashar al-Assad. In practice, organizations fully approving of the primacy of government in Syria could exist. The most important organization linked to the Assad regime is the Popular Front of the Liberation of Palestine-General Command (PFLPGC), controlled by Ahmad Jibril. A second pro-Assad organisation is al-Sai'qa,

${ }^{23}$ Palestinian Refugees from Syria: Ongoing Nakba, Ongoing Discrimination, op. cit., p. 3.

${ }^{24}$ E. Gordts, Caught Between ISIS And Assad, A Palestinian Refugee Camp Is Starving To Death (in:) http://www.huffingtonpost.com/2015/04/09/syria-yarmouk-isis_n_7029632.html, access: April 29, 2015.

${ }^{25} \mathrm{He}$ is a senior analyst at the Jerusalem Center for Public Affairs.

${ }^{26}$ P. Inbari, The Arab Awakening and the Palestinian Refugee Problem, "The Israel Journal of Foreign Affairs", Volume 7, No. 3, p. 47, http://www.israelcfr.com/documents/7-3/7-3-4PinhasInbari.pdf, access: April 29, 2015.

${ }^{27}$ M. Qandil, Reports; The Syrian Revolution and the Palestinian Refugees in Syria: Realities and risks (May 2002), p. 2-3, Al-Jazierra Centre for Studies, http://studies.aljazeera.net/ ResourceGallery/media/Documents/2012/5/2/201252132022536734The\%20Syrian\%20Revolution\%20and\%20Palestinian\%20Refugees\%20in\%20Syria.pdf, access: April 29, 2015. 
a political and military Palestinian branch of the Ba'ath Party that exists only in Syria, but even in this country its importance is $\operatorname{minor}^{28}$

The PFLP-GC has always supported the Syrian regime and has been an ally of the Ba'ath Party government. This group was created in 1968 by Ahmed Jibril, who had left PLO. At first, PFLP-GC was a secular Marxist-Leninist organization, but in the late 1980s it began to emphasize its religious elements. The PFLP-GC has its own military formation, called the Jihad Jibril Brigades. The strongest structure of this organization is located in Syria, but it is also present in Lebanon, Gaza, West Bank ${ }^{29}$. Tariq Hammound rightly pointed out: "The position of the PFLP-GC has a certain degree of importance in Syria. Despite the weak and symbolic presence of the organization inside Palestine, its presence in Syria is the strongest and largest in comparison to its presence in other countries, in addition to the fact that it possesses considerable military resources and experience. Thus, the stance of the PFLP-GC has a direct impact on the course of events in Syria" ${ }^{30}$. He added: "The PFLP-GC has adopted two simultaneous positions since the beginning of the events: individually it asserted the truth of the regime's narrative, which can be seen in its statements and media but when taking collective stances with other Palestinian factions, the organization stuck to the position of neutrality" 31 .

The neutral attitude of the PFLP-GC toward the revolution collapsed in no time. In August 2011, Ahmad Jibril declared his support for President Assad. He was accused of making a decision without consulting the group's leadership. Also, Jibril was criticized for giving consent to arming Palestinians in the Yarmouk refugee camp ${ }^{32}$. These decisions were motivated by some events, e.g., arson at the $\mathrm{Al}$ Khalisa House, headquarters of the PFLP-GC in al Yarmouk camp ${ }^{33}$. Earlier, rumors appeared that claimed that the PFLP-GC, hand in hand with Syrian security forces, was involved in suppressing Syrian protesters. The PFLP-GC had no alternatives and had to support the regime. The Assad administration is its only ally and sponsor. Activities the PFLP-GC were concentrated in Yarmouk camp. By December 2012, the rebels had won control of Yarmouk. All parties signed an agreement that called for withdrawing all armed groups, leaving the camp as a neutral zone and disman-

${ }^{28}$ T. Hammound, op. cit., p. 24.

${ }^{29} \mathrm{http}: / /$ www.maannews.com/Content.aspx?id=510710, access: April 29, 2015.

${ }^{30}$ T. Hammound, op. cit., p. 24.

${ }^{31}$ Ibidem.

${ }^{32} \mathrm{http}: / /$ www.maannews.com/Content.aspx?id=510710, access: April 29, 2015.

${ }^{33}$ In this house five persons were killed. The Impact of the Syrian Revolution on Palestinian Refugees, Palestinian Return Centre, "Journal of Palestinian Refugee Studies", http://www. prc.org.uk/portal/index.php/english-media/jprs-magazine/2889-the-impact-of-the-syrian-revolution-on-palestinian-refugees/2889-the-impact-of-the-syrian-revolution-on-palestinian-refugees, access: April 29, 2015. 
tling the PFLP-GC. The PFLP-GC is still fighting but its importance has fallen ${ }^{34}$. In April 2015 militants of this group continued to fight against ISIS ${ }^{35}$.

Also, GAPAR tried to support the Syrian regime. In a July 2016 letter to Peter Krahenbuhl, Commissioner-General of United Nations Relief and Works Agency for Palestine Refugees in the Near East (UNRWA), the GAPAR stressed "that terrorist rocket, mortar, and sniper attacks in Aleppo are targeting Palestinian refugee camps there, and that the unjust and illegal sanctions imposed on Syria have serious negative effects on both Syrians and Palestinian refugees, calling for lifting these unilateral sanctions" ${ }^{36}$. It also pointed out "that the importance of the standing cooperation and coordination between the Syrian government and the UNRWA to implement the 2016 humanitarian response plan for the Palestinian refugees and in delivering aid to them" ${ }^{37}$.

\section{ANTI-ASSAD PALESTINIANS}

Palestinian refugees did not claim responsibility for start of protests, but some Palestinians, especially young people, supported the demands of the demonstrators. Together with the expansion of the rebellion, more and more Palestinian refugees openly sided with the rebels. The Syrian Army has attacked several Palestinian camps. In May 2012, the army bombed the Darra camp (at least 20 people were killed). In August, fights broke out between Assad's forces and rebels in Yarmouk ${ }^{38}$. In October 2012, the Liwa al-Asifa (Storm Brigade), which supported the Free Syrian Army, was created in Yarmouk. This formation fought against the PFLP-GC and on December 2012, hand in hand with the Free Syrian Army, it took control over the camp ${ }^{39}$ The author has not found further information about Palestinian formations fighting on the opposition side, but surely some Palestinians (we don't know how many) supported various opposition groups.

${ }^{34}$ Official: Peace agreement foiled in Yarmouk as PFLP-GC redeploys, http://www.maannews.com/Content.aspx?id=657777, access: April 30, 2015.

${ }^{35}$ According to Anwar Raja, the spokesman for Damsascus-based PFLP-GC, several pro-Assad factions have united to defend the camp. J. Hall, Now ISIS incurs the wrath of Hamas: Islamic State ransacks Syria's Yarmouk refugee camp and massacres residents - prompting vow of revenge from Palestinian fighters, http:/www.dailymail.co.uk/news/article-3027229/Now-ISIS-incurs-wrath-Hamas-Islamic-State-ransacks-Syria-s-Yarmouk-refugee-camp-massacres-residentsprompting-vow-revenge-Palestinian-fighters.html, access: April 30, 2015.

${ }^{36}$ GAPAR calls for stopping terrorist attacks on Palestinian refugees in Syria, http://sana.sy/ en/?p=79957, September 5, 2016.

${ }^{37}$ Ibidem.

${ }^{38}$ E. Benari, Syria shuts down Hamas offices, http://www.israelnationalnews.com/News/ News.aspx/161750\#.VUDg9P1_v5P, access: April 29, 2015.

${ }^{39}$ J. Paraszczuk, Capturing Yarmouk camp another Syrian rebel gain, http://www.jpost.com/ Middle-East/Capturing-Yarmouk-camp-another-Syrian-rebel-gain, access: April 29, 2015. 


\section{EXTERNAL PALESTINIAN PARTIES AND THE SYRIAN CONFLICT}

The attempt to be neutral was also typical of Palestinian organizations outside Syria.

\section{HAMAS}

Hamas was in a particularly difficult situation. Relationships between Hamas and the Assad regime were very close. The Syrian government supported Hamas financially, politically, and logistically. Hamas' consultative council and the main headquarters of its leader were located in Damascus. Hamas is a radical, Sunni Islamic organisation. Its ideology is connected with the demands of some of the protesters. Moreover, most of these demonstrators were Sunni. At the beginning of the Syrian uprising Hamas tried to be a mediator between the Syrian government and the opposition, but it changed its attitude in 2012. In January 2012 Khaled Meshaal left Damascus and in February 2012 prime minister Ismail Hanija supported the Syrian opposition. During Friday prayer, he said, "I salute all people of the Arab Spring, or Islamic winter, and I salute the Syrian people who seek freedom, democracy and reform". After this speech, the worshipers shouted back, "God is great" and "Syria! Syria!" 40 . Meshaal explained his attitude towards Assad regime: "There is no doubt that we have disagreed with the Syrian regime on the manner with which they managed the crisis, and their resorting to the security-military option," He added "The massacre taking place in Syria pains us very much. We were forced to leave Damascus even though the regime used to support us. We also had differences with Iran on what goes on in Syria"41. After this declaration, Syria ceased to be an asylum for Hamas members. Two of its leaders were shot dead by Syrian soldiers in the Daraa camp in October 2012 $2^{42}$. In January 2013, the bodies of two other leaders were found in the Husseinieh camp. They were probably executed by Syrian security forces ${ }^{43}$ and in November 2012 state security forces shut down all Hamas offices in Syria ${ }^{44}$. The change in Hamas' stance

${ }^{40}$ F.Akram,In Break, Hamas Supports Syrian Opposition, http://www.nytimes.com/2012/02/25/ world/middleeast/hamas-leader-supports-syrian-opposition.html?_r=0, access: April 29, 2015.

${ }^{41}$ Hamas and Fatah in unity talks, says Khaled Meshaal, http://www.bbc.com/news/worldmiddle-east-21363104, access: April 29, 2015.

422 Hamas leaders killed in Syria, sources say, http://www.maannews.com/Content.aspx?id=532288, access: April 29, 2015.

${ }^{43}$ NGO accuses Damascus of killing two Hamas members in Syria, http://english.ahram.org. eg/NewsContent/2/8/62088/World/Region/NGO-accuses-Damascus-of-killing-two-Hamas-members-.aspx, access: April 29, 2015.

${ }^{44}$ Syria Shuts Down Hamas Offices, http://www.israelnationalnews.com/News/News.aspx/ 161750\#.VUDg9P1_v5P, access: April 29, 2015. 
was visible on the streets of Gaza. Hamas authorities allowed residents of Gaza to stage protests against Syrian government ${ }^{45}$.

Cooperation between Hamas and Syrian rebels was becoming closer. In April 2013, Israeli newspapers reported that the Izz ad-Din al-Qassam Brigades (paramilitary wing of Hamas) had begun training Free Syrian Army units ${ }^{46}$. One Hamas activity was helping the rebels dig and construct tunnels ${ }^{47}$. Hamas leaders have denied any affiliation with the Syrian rebels. One Hamas official in Lebanon, Osama Hamdan, said "It's a false thing. There are no members of Izzadin Kassam or any militant members of Hamas in Syria... We don't interfere in the internal problems of Syria. Our members there are normal civilians, Syrian Palestinians, who live with their families there. From the beginning of what has happened in Syria we rejected as a movement any involvement of any Palestinian in the current events in Syria"48. But journalists have reported on Hamas' involvement have still informed about Hamas involvement in the civil war. In the Yarmouk camp, a Palestinian militia loyal to Hamas Aknaf Beit al-Maqdis was established in 2013. At the beginning, it supported the rebels but after the ISIS invasion this group joined the Syrian Government forces ${ }^{49}$.

ISIS is a more serious enemy for Hamas. On $6^{\text {th }}$ April 2015, in Gaza, several hundred supporters of Hamas staged a march in the Jebaliya refugee camp to protest ISIS' takeover of parts of Yarmouk. Mohammed Abu Askar, a local Hamas leader, said that "Palestinian blood is not cheap" self-declared caliphate often criticized the actions and ideology of Hamas. In July, 2015 it issued an official statement addressed to the "Tyrants of Hamas". "The rule of shariah (Islamic law) will be implemented in Gaza, in spite of you. We swear that what is happening in the Levant today, and in particular the Yarmouk camp, will happen in Gaza" ${ }^{51}$.

${ }^{45}$ S. Nashashibi, ...

${ }^{46} \mathrm{~J}$. Davidowich, Hamas reportedly training rebels, fighting to oust Assad, http://www.timesofisrael.com/hamas-reportedly-training-rebels-fighting-to-oust-assad/; Military wing of Hamas training Syrian rebels, http://www.jpost.com/Middle-East/Hamas-reportedly-training-Syrian-rebels-in-Damascus-308795, access: April 29, 2015.

${ }^{47}$ At the time FSA prepared an attack on Damascus. Military wing of Hamas training Syrian rebels, http://www.jpost.com/Middle-East/Hamas-reportedly-training-Syrian-rebels-in-Damascus-308795, access: April 29, 2015.

${ }^{48}$ Ibidem.

49 'ISIS and Nusra are one' in Yarmouk Camp https://www.middleeastmonitor.com/articles/ middle-east/18134-isis-and-nusra-are-one-in-yarmouk-camp, access: April 30, 2015.

${ }^{50}$ J. Hall, Now ISIS incurs the wrath of Hamas: Islamic State ransacks Syria's Yarmouk refugee camp and massacres residents - prompting vow of revenge from Palestinian fighters, http:// www.dailymail.co.uk/news/article-3027229/Now-ISIS-incurs-wrath-Hamas-Islamic-State-ransacks-Syria-s-Yarmouk-refugee-camp-massacres-residents-prompting-vow-revenge-Palestinianfighters.html, access: April 30, 2015.

${ }^{51}$ The statement included the information about necessity to fight agains Fatah and Jewish State. A. Abdelaty, WATCH: ISIS Vows to Topple Hamas in Gaza, Uproot , State of the Jews ',Haaretz", http://www.haaretz.com/middle-east-news/1.663836, access: August 30, 2016. 
Hamas' attitude towards the fighting parties in Syria has been ambiguous. Its leaders realized that their opposition to forces loyal to President Assad might affect relations with Iran, all the more that in 2016 Hamas was trying to rebuild its relations with Tehran ${ }^{52}$.

\section{PALESTINIAN LIBERATION ORGANISATION}

The Palestinian Liberation Organisation officially declared its neutrality at the beginning of the conflict. Palestinian authorities tried to maintain a non-interference policy into the internal affairs in the Arab world. This strategy is calculated so as not to put the "Palestinian refugees" at the heart of conflicts. The Palestinian government was trying to protect the refugee camps and they even sent an official delegation to Damascus. Abu Rudeineh, spokesman for the Palestinian Authority in Ramallah, said "[We tried] to lift the siege on them and save the poor Palestinians there from starvation". He emphasized "when it comes to the crisis in Syria, it is important to keep moving toward a peaceful solution". This Palestinian politician added that they should encourage dialogue and support the second Geneva conference. According to Dalit Halevy and Tova Dvorin, Israeli journalists, "contrary to the frequent accusations against Israel by the PA for alleged "war crimes" against the Palestinian Arabs, Abbas has avoided commenting on the war crimes proven by the UN to have been perpetuated against the Syrian people by President Bashar Assad" ${ }^{\prime 3}$. Indeed, Palestinian authorities were not too active. Even during traumatic events PLO representatives are limited to criticize military actions. In August 2012, Palestinian president Mahmud Abbas condemned the attack on Yarmouk camp and called for an end to violence in refugee camps, but stressed in the same statement that ,the Palestinian position towards Syria was not to interfere in Syrian internal affairs" and added that „refugee camps in the country would remain neutral" 54 .

At the same time, there were different stances within the PLO. There are politicians who clearly condemned the actions of the Syrian authorities. One of them was Yasser Abed Rabbo, the PLO's secretary-general. He described an August 2011 attack by Assad's forces on a Palestinian camp in Latakia as "a crime against humanity". He said "the shelling is taking place using gunships and tanks on houses built from tin, on people who have no place to run to or even a shelter

${ }^{52} \mathrm{H}$. Balousha, Why Hamas resumed ties with Iran, http://www.al-monitor.com/pulse/originals/2016/06/gaza-hamas-resume-relations-iran.html, access: October 27, 20116

${ }^{53}$ D. Halevy, T. Dvorin, Abbas Refrains from Condemning Syrian War Crimes, http://www. israelnationalnews.com/News/News.aspx/177825\#.VUM-Qfl_v5M, access: April 30, 2015

${ }^{54}$ Abbas condemns Syria attack on Palestinian camp, http://www.maannews.com/Content. aspx?id=509674, access: April 30, 2015. 
to hide in" ${ }^{55}$. But Nour Abdulhadi, the PLO's director for political affairs in Syria, said Palestinian refugees "will remain as supporters of the Syrian government"

The rhetoric of the PLO changed slightly after Daesh attack on Yarmouk camp. On $4^{\text {th }}$ April 2015, the Executive Committee Members made a statement. At the beginning of the documents, the PLO confirmed its neutrality. "Al-Yarmouk refugee camp continues to be the victim of the internal Syrian conflict despite the repeated reiteration by the Palestine Liberation Organization (PLO) and the vast majority of the Palestinian groups of our longstanding position of non-interference in the internal affairs of other states" $" 57$. The statement then noted the "kidnappings, beheadings and mass killings are coming out from Al-Yarmouk, which is under a brutal campaign of murder and occupation at the hands of the terrorist group of Daesh and its allies". The statement ended with a reiteration of the Palestinians' right of return: "This humanitarian disaster is a further reminder of the need to realize the inalienable right of return for all Palestine refugees, in line with international law and relevant UN resolutions. In the meantime, the tragedy unfolding in Al-Yarmouk shall remain a testament to the collective human failure of protecting civilians in times of war". However, at the same time, President Abbas still emphasized the need to be neutral. "We urge those wanting to drag us in the conflicts to keep us away as we have been suffering and anguishing from many wars everywhere (...) We announced more than four years ago that we have not interfered in the internal affairs of any Arab country and therefore we reject any interference in our affairs. We have no relations with what is going on in Syria"58.

A few days later newspapers reported an agreement between the Syrian president Assad's regime and Palestinian factions for a joint military operation against ISIS in Yarmouk. This declaration was announced by PLO official Ahmed Majdalani, who was head of a delegation to Damascus. Members of the Palestinian executive body were "very upset" with Majdalani's breaking of the PLO's official line ${ }^{59}$. They made another statement, this time official: "we call for resorting to other means to spare the blood of our people and prevent more destruction and displacement for the Palestinians in al-Yarmouk Refugee Camp," It added "we refuse to be drawn into any armed campaign" ${ }^{\circ}$. Palestinian President Mahmoud

${ }^{55}$ PLO official accuses Syria of crimes against humanity, http://www.reuters.com/article/ 2011/08/16/us-syria-palestinians-plo-idUSTRE77F2DN20110816, access: April 30, 2015.

${ }^{56} \mathrm{~S}$. Nashashibi, op. cit.

${ }^{57}$ Statement by PLO Executive Committee Member, Dr. Saeb Erekat on the situation at Al Yarmouk Camp, http://nad-plo.org/userfiles/file/statements/Dr_Erekat_on_the_situation_at_Al_ Yarmouk_Camp.pdf, access: April 30, 2015.

${ }^{58}$ Israeli Arab MK: World Ignoring ISIS Massacre of Palestinians, http://www.haaretz.com/ middle-east-news/1.650714, access: August 30, 2016.

${ }^{59}$ Ahmad Majdani is the secretary-general of the Palestinian Popular Struggle Front and this faction is supported for the Assad regime. J. Moore, Palestinian Envoy Broke PLO Line to Agree Yarmouk Deal With Assad Regime, http://europe.newsweek.com/palestinian-envoy-broke-officialplo-line-agree-yarmouk-deal-assad-regime-321287?rm=eu, access: August 30, 2016,

${ }^{60}$ Ibidem. 
Abbas said that residents of Yarmouk had been victimized by Syria's civil war. Government forces and different rebel factions were clashing and "we pay the price". He also declared "we are in touch with our brothers there to find a way out and protect our people" 61 .

These situations reflect the tensions inside the PLO, but the PLO policy of neutrality will be maintained, even though the vast majority of Palestinians are against Assad. According to June 2016 opinion polls, only 18 percent of Palestinians favoured Assad, 40\% were in favor of the Syrian Free Army, and 5\% in favor of radical Islamists such as ISIS ${ }^{62}$. The leaders of PLO realized that taking a clear position would have serious political meaning and it worsen their international position.

\section{THE SITUATION OF PALESTINE REFUGEES IN SYRIA}

The war in Syria is a tragedy for civilians, including Palestinian refugees. Palestinian camps have been attacked, bombed and besieged. According to the Syria Needs Analysis Project, in March 2014 the conflict was characterized by high intensity in four Palestinian camps in March 2014 (Ein Al-Tal (Handarat), Deirab - near to Aleppo, Yarmouk and Dara). Three of them were closed and UNRWA operations were suspended in the fourth ${ }^{63}$. Palestinian refugees were being killed in other camps, e.g., there were several airstrikes on Khan Eshieh camp in July $2016^{64}$. According to the Palestinian Embassy in Syria, the number of Palestinians confirmed killed during the ongoing civil conflict had reached around $1200-1300$ by December 2014, while an equal number were considered missing ${ }^{65}$. In July 2016, the UK-based Action Group for Palestinians in Syria documented the deaths of at least 3,274 Palestinians. At least 1,083 Palestinians are locked up in Syrian government prisons and another 286 are missing ${ }^{66}$.

Media often reported about the situation in Yarmouk, the biggest Palestinian camp in Syria. In 2012 there was fighting in the camp between Free Syrian Army and its Palestinian ally Liwa al-Asifa on the one hand, and government army supported by the PFLP-GC on the other. The camp has been besieged since July 2013. Before the war it was home to some 160000 Palestinians. In April 2015,

${ }^{61}$ J. Hall, op. cit.

${ }^{62}$ Palestinian Public Opinion Poll No (60), http://www.pcpsr.org/en/node/658, access: October 27, 2016.

${ }^{63}$ Palestinians from Syria. Syria Needs Analysis Project-March 2014

${ }^{64}$ P. Strickland, D. Collins, Palestinian refugees killed in Syria's Khan Eshieh camp, http://www.aljazeera.com/news/2016/07/palestinian-refugees-killed-syria-khan-eshieh-camp160701160957338.html

${ }^{65}$ Embassy: Around 2,500 Palestinians dead or missing in Syria war https://www.maannews.com/Content.aspx?id=749815, access: April 30, 2015; August 30, 2016.

${ }^{66}$ P. Strickland, D. Collins, op. cit. 
the Syrian government said only 6000 remain $^{67}$. The situation in the camp has been dramatic. In February 2014 Filippo Grandi, head of UNRWA, described the camp "as a ghost town". "The devastation is unbelievable. There is not one single building that I have seen that is not an empty shell by now. They're all blackened by smoke". He described situation of the camp's residents: "It's like the appearance of ghosts. These are people who have not been out of there, that have been trapped in there not only without food, medicines, clean water-all the basics - but also probably completely subjected to fear because there was fierce fighting ... They can hardly speak. I tried to speak to many of them, and they all tell the same stories of complete deprivation"68.

Unfortunately, in April 2015 the situation became even more dramatic. On 1 April 2015 ISIS fighters entered the camp. Pierre Krahenbuhl, head of UNRWA, told a meeting of the Security Council about the "extreme circumstances and hardship" in the camp ${ }^{69}$ (according to UNWRA, 18000 residents lived in Yarmouk ${ }^{70}$ ). The press reported that two hundred people had starved to death within the camp ${ }^{71}$. On 20 April 2015, the members of the Security Council "expressed their deep concern regarding the grave humanitarian situation in Yarmouk Refugee Camp in Syria" and "called for unhindered humanitarian access to the Yarmouk Camp and for the protection of civilians inside the Camp". The Security Council also adopted "a three-point plan that includes: 1) Providing assistance for civilians who are unwilling or unable to leave Yarmouk; 2) Assisting those who want to "temporarily relocate" from the camp to do so in accordance with international humanitarian law and with appropriate safeguards that they will be allowed to do so safely and freely; and 3) Assisting Yarmouk residents who have already fled". The Council „condemned all acts of terrorism perpetrated and demanded that ISIL and Al-Nusra Front" and ordered them to "withdraw from Yarmouk Camp immediately" ${ }^{\prime 2}$. Yarmouk Camp was finally taken over by ISIS and the al-Nusra Front. As a result, the population has dropped to c. 8,000 civilians. The situation

${ }^{67}$ Un demands unobstructed access to Syria's Yarmouk camp, http://www.aljazeera.com/ news/2015/04/demands-unobstructed-access-syria-yarmouk-camp-150421155108878.html, access: April 30, 2015.

${ }^{68} \mathrm{H}$. Sherwood, Queue for food in Syria's Yarmouk camp shows desperation of refugees "The Guardian", http://www.theguardian.com/world/2014/feb/26/queue-food-syria-yarmouk-campdesperation-refugees, access: April 30, 2015.

${ }^{69}$ Un demands unobstructed access to Syria's Yarmouk camp...

${ }^{70} \mathrm{http} / / / \mathrm{www}$.unrwa.org/newsroom/emergency-reports/syria-regional-crisis-response-update-86, access: April 30, 2015.

${ }^{71}$ J. Moore, Syria Offers to Arm Yarmouk's Palestinian Refugees to Fight ISIS, http://www. newsweek.com/syria-offers-arm-yarmouks-palestinian-refugees-fight-isis-320692, access: April 30, 2015.

72 Security Council Press Statement on Yarmouk Refugee Camp, Security Council, Press Release, http://www.un.org/press/en/2015/sc11865.doc.htm, access: April 30, 2015. 
in the camp was dramatic; some people starved to death ${ }^{73}$. Only in February 2016 was UNRWA able to deliver aid to the camp's neighbouring areas - for the first time in nine months ${ }^{74}$ But in April 2016 UNWRA's humanitarian operations were interrupted due to intensifying fights ${ }^{75}$.

The situation of Yarmouk residents demonstrates the experience of all Palestinian civilians who were in the heat of battle. After the outbreak of the conflict, Palestinians were deprived of many rights. In Summer 2015 Katrien de Bock reported "at the moment most of them face the continuous risk of being arbitrarily arrested or tortured. In 2012, the Ministry of Education and Higher Education even excluded Palestinian students from its public schools"76. According to UNRWA all 560000 registered Palestinian refugees in Syria have been affected by the ongoing conflict. It estimates that $95 \%$ of the 480000 Palestine refugees remaining in Syria are in continuous need of humanitarian aid. "The escalating violence makes movement and access more difficult and causes severe hardship". 280000 Palestinians remaining in Syria are internally displaced ${ }^{77}$. By October 2016 over $40 \%$ of the Palestinians camps in Syria have been engulfed by conflict. Five of the twelve Palestine refugee camps--Ein el Tal, Dera, Yarmouk, Sbeineh and Khan Eshieh--were either destroyed or inaccessible to UNWRA ${ }^{78}$. In Summer 2015 Al- Majdal reported "the camp of Khan Eshieh is besieged by mortar shelling and clashes, with the presence of armed groups inside the camp. Here, Palestinians are allowed to leave the camp in order to receive food assistance, but they are not allowed to bring anything else back into the camp. Al-Yarmouk camp experiences ongoing clashes and shelling, and Ein Al-Tal suffered from intense clashes in January 2015"79. According to the Jafra Foundation, 60\% of the Dera camp was reportedly destroyed by July 2016 , while $80 \%$ of the Sbeineh camp was demolished ${ }^{80}$. In addition, 80000 Palestinian refugees in Syria have

${ }^{73}$ Aid reaches Syria's Yarmouk camp after nine months (14 February 2016) http://www. aljazeera.com/news/2016/02/aid-reaches-syria-yarmouk-camp-months-160213185821793. html, October 25, 2016.

${ }^{74}$ P. Strickland, Q\&A: Beyond Yarmouk, Palestinians in Syria need aid (25 February 2016), http://www.aljazeera.com/news/2016/02/qa-yarmouk-palestinians-syria-aid-160224125117212. html, access: October 25, 2016.

${ }^{75}$ Syria Palestine refugees Humanitarian sbapshot, April 2016, http://www.unrwa.org/resources/reports/syria-palestine-refugees-humanitarian-snapshot-april-2016, access: October 25, 2016,

${ }^{76}$ K. de Bock, Palestinian Refugees in Syria: an overview (in) Palestinian Refugees from Syria: Ongoing Nakba, Ongoing Discrimination No 2, Al Majdal No 57, (Summer 2015), p. 5 http://www.badil.org/phocadownload/badil-new/publications/periodicals/al-majdal/al-majdal-57. pdf, access: October 25, 2016.

${ }_{77}$ The Syria Crisis https://europa.eu/eyd2015/en/unrwa/posts/syria-crisis October 25, 2016.

${ }^{78} \mathrm{http} / / /$ www.unrwa.org/galleries/photos/unrwa-and-palestine-refugees-syria-facts-and-figures, access: October 25, 2016.

${ }^{79}$ K. de Bock, op. cit., p. 3.

${ }^{80}$ P. Strickland, D. Collins, Palestinian refugees killed in Syria's Khan Eshieh camp, http://www.aljazeera.com/news/2016/07/palestinian-refugees-killed-syria-khan-eshieh-camp160701160957338.html, access: October 25, 2016. 
fled abroad. By Summer 2015 there were 44000 in Lebanon, 15000 in Jordan, 10 000-15 000 in Turkey and 4000 in Egypt. Considerable numbers were in Europe and beyond ${ }^{81}$. Unfortunately, Jordan effectively closed its borders to Palestinian refugees early in the conflict, Lebanon planned to do the same in May $2015^{82}$.

The most important organization trying to help Palestinian refugees in Syria is UNRWA. In 2016 it launched an appeal for $\$ 414$ million, but at the beginning of October 2016 only $50 \%$ of the requested sum had been received. UNRWA urges its donors to continue and increase their help to protect Palestinian refugees ${ }^{83}$. In addition to UNWRA, the EU has created a separate fund, Maintaining the Resilience of Palestine Refugees from Syria in Jordan and Lebanon, for Palestinian refugees. It allocated 15 million Euro for this Fund in $2016^{84}$.

\section{CONCLUSION}

Palestinians constitute a small part of Syrian society, and they are marginalized in the ongoing conflict. A report prepared by the U.S. Congressional Reference Service in September 2016 reveals the scale of this marginalization; it does not mention the Palestinians at all ${ }^{85}$. What is more, the parties to the conflict have not been interested in Palestinian refugees. It is also worth mentioning that the main authorities of Palestine try to keep their distance from the conflict and pursue a policy of neutrality - the PLO is following this policy all the time and Hamas used to support the rebels, but its attitude towards the Syrian parties is now ambiguous. Residents of the Palestinian camps also attempted to be neutral, but they quickly lost subjectivity and became victims. Unfortunately, this is not the first time Palestinians have been victims.

${ }^{81}$ Palestinian Refugees from Syria: Ongoing Nakba, Ongoing Discrimination No 2, Al Majdal No 57, (Summer 2015), p. 3, http://www.badil.org/phocadownload/badil-new/publications/ periodicals/al-majdal/al-majdal-57.pdf, access: October 25, 2016. According to the UNWRA in December 2014 there were more than 800 refugees in Gaza, http://www.unrwa.org/newsroom/ emergency-reports/syria-regional-crisis-response-update-82, access: October 25, 2016.

82 http://www.unrwa.org/syria-crisis April 30, 2015.

${ }^{83}$ UNRWA and Palestine refugees in Syria: Facts and Figures, http://www.unrwa.org/galleries/photos/unrwa-and-palestine-refugees-syria-facts-and-figures, access: October 25, 2016.

${ }^{84} \mathrm{http}$ ://ec.europa.eu/enlargement/neighbourhood/countries/syria/madad/2016/20160912action-doc-maintaining-resilience-of-the-palestinian-refugees.pdf, access: October, 25, 2016.

${ }^{85}$ Armed Conflict in Syria: Overview and U.S. Response, https://www.fas.org/sgp/crs/mideast/RL33487.pdf, access: October 26, 2016. 


\section{BIBLIOGRAPHY}

1. Abdelaty A., WATCH: ISIS Vows to Topple Hamas in Gaza, Uproot 'State of the Jews '"Haaretz" July 1, 2015, http://www.haaretz.com/middle-east-news/1.663836.

2. Action Document for EU Trust Fund to be used for the decisions of the Operational Board, http://ec.europa.eu/enlargement/neighbourhood/countries/syria/madad/2016/20160912-action-doc-maintaining-resilience-of-the-palestinian-refugees.pdf.

3. Armed Conflict in Syria: Overview and U.S. Response, Federation American Scientits https:// www.fas.org/sgp/crs/mideast/RL33487.pdf .

4. Ali Z., Zayed A., The Arab Spring and Reviving the Hope of Return, No 52, Spring 2013, http:// www.badil.org/en/al-majdal/item/1928-art6.

5. Akram F., In Break, Hamas Supports Syrian Opposition „New York Times” February 24, 2012, http://www.nytimes.com/2012/02/25/world/middleeast/hamas-leader-supports-syrian-opposition.html?_r=0.

6. Balousha H., Why Hamas resumed ties with Iran „Al Monitor” December 14, 2014, http://www. al-monitor.com/pulse/originals/2016/06/gaza-hamas-resume-relations-iran.html.

7. Benari E., Syria shuts down Hamas offices „Arutz Sheva 7” November 6, 2012, http://www. israelnationalnews.com/News/News.aspx/161750\#.VUDg9P1_v5P.

8. Davidowich J., Hamas reportedly training rebels, fighting to oust Assad „The Times of Israel" April 5, 2013, http://www.timesofisrael.com/hamas-reportedly-training-rebels-fighting-to-oust-assad.

9. de Bock K., Palestinian Refugees in Syria: an overview (in) Palestinian Refugees from Syria: Ongoing Nakba, Ongoing Discrimination No 2, Al Majdal No 57, (Summer 2015), p. 5, http:// www.badil.org/phocadownload/badil-new/publications/periodicals/al-majdal/al-majdal-57.pdf .

10. Hall J., Now ISIS incurs the wrath of Hamas: Islamic State ransacks Syria's Yarmouk refugee camp and massacres residents - prompting vow of revenge from Palestinian fighters „Mail Online”, April 6, 2015, http://www.dailymail.co.uk/news/article-3027229/Now-ISIS-incurs-wrath-Hamas-Islamic-State-ransacks-Syria-s-Yarmouk-refugee-camp-massacres-residents-prompting-vow-revenge-Palestinian-fighters.html.

11. Halevy D., Dvorin T., Abbas Refrains from Condemning Syrian War Crimes „Arutz Sheva 7" February 25, 2014, http://www.israelnationalnews.com/News/News.aspx/177825\#.VUMQfl_v5M.

12. Hammound T., Palestinian Refugees and the Syrian Revolution, Arab Center for Reaserch Policy Studies, Doha (February 2013).

13. Inbari P., The Arab Awakening and the Palestinian Refugee Problem, "The Israel Journal of Foreign Affairs", Volume 7, No. 3, p. 47, http://www.israelcfr.com/documents/7-3/7-3-4PinhasInbari.pdf.

14. Moore J., Palestinian Envoy Broke PLO Line to Agree Yarmouk Deal With Assad Regime, "Newsweek" October 4, 2015, http://europe.newsweek.com/palestinian-envoy-broke-officialplo-line-agree-yarmouk-deal-assad-regime-321287?rm=eu.

15. Moore J., Syria Offers to Arm Yarmouk's Palestinian Refugees to Fight ISIS "Newsweek" October 4, 2015, http://www.newsweek.com/syria-offers-arm-yarmouks-palestinian-refugees-fight-isis-320692.

16. Nashashibi S., The Palestinian dilemma over Syria "The Guardian" July 27, 2012, http://www. theguardian.com/commentisfree/2012/jul/27/palestinian-dilemma-syria.

17. Palestinian Public Opinion Poll No (60), http://www.pcpsr.org/en/node/658. 
18. Palestinian Refugees from Syria: Ongoing Nakba, Ongoing Discrimination "Al Majdal", BADIL Resource Center for Palestinian Residency and Refugee Rights, Issue No.56 (Autumn 2014), http://badil.org/phocadownload/Badil_docs/publications/al-majdal-56.pdf.

19. Palestinian Refugees from Syria: Ongoing Nakba, Ongoing Discrimination No 2, "Al Majdal”, BADIL No 57, (Summer 2015), http://www.badil.org/phocadownload/badil-new/publications/ periodicals/al-majdal/al-majdal-57.pdf.

20. Palestinians from Syria. Syria Needs Analysis Project-March 2014, http://reliefweb.int/sites/ reliefweb.int/files/resources/palestinians_from_syria_march_2014.pdf.

21. Paraszczuk J., Capturing Yarmouk camp another Syrian rebel gain' ,, The Jerusalem Post' December 19, 2012, http://www.jpost.com/Middle-East/Capturing-Yarmouk-camp-another-Syrian-rebel-gain.

22. Shafie S., Palestinian refugees in Syria, http://www.forcedmigration.org/research-resources/ expert-guides/palestinian-refugees-in-syria/fmo017.pdf.

23. Harriet S., Queue for food in Syria's Yarmouk camp shows desperation of refugees "The Guardian" February 26, 2014, http://www.theguardian.com/world/2014/feb/26/queue-food-syria-yarmouk-camp-desperation-refugees.

24. Strickland P., Collins D., Palestinian refugees killed in Syria's Khan Eshieh camp, "Al Jazzeera" July 2, 2016, http://www.aljazeera.com/news/2016/07/palestinian-refugees-killed-syria-khan-eshieh-camp-160701160957338.html.

25. Strickland P., Q\&A: Beyond Yarmouk, Palestinians in Syria need aid "Al Jazeera" February 25, 2016, http://www.aljazeera.com/news/2016/02/qa-yarmouk-palestinians-syria-aid-160224125117212.html.

26. The Impact of the Syrian Revolution on Palestinian Refugees, Palestinian Return Centre, "Journal of Palestinian Refugee Studies", http://www.prc.org.uk/portal/index.php/english-media/ jprs-magazine/2889-the-impact-of-the-syrian-revolution-on-palestinian-refugees/2889-the-impact-of-the-syrian-revolution-on-palestinian-refugees.

27. Un demands unobstructed access to Syria's Yarmouk camp “Al Jazeera” April 21, 2015, http://www.aljazeera.com/news/2015/04/demands-unobstructed-access-syria-yarmouk-camp-150421155108878.html.

28. UNRWA, www.unrwa.org. 